Article

\title{
Emotional Education for the Development of Primary and Secondary School Students Through Physical Education: Literature Review
}

\author{
Sebastián Espoz-Lazo ${ }^{1}$, Raquel Rodríguez Huete ${ }^{1}$, Pablo Espoz-Lazo ${ }^{2}$, \\ Claudio Farías-Valenzuela ${ }^{1,3}$ (D) and Pedro Valdivia-Moral $1, *$ (D) \\ 1 Department of Didactics of Music, Plastics and Corporal Expression, Faculty of Education, University of \\ Granada, 18010 Granada, Spain; s.espoz.1@gmail.com (S.E.-L.); raquel16@correo.ugr.es (R.R.H.); \\ claudio.farias.v@usach.cl (C.F.-V.) \\ 2 Facultad de Medicina, Universidad Andres Bello, Santiago 8370321, Chile; p.espoz@unab.cl \\ 3 Laboratory of Sciences of Physical Activity, Sport and Health, Faculty of Medical Sciences, Universidad de \\ Santiago de, Santiago 9170022, Chile \\ * Correspondence: pvaldivia@ugr.es
}

Received: 19 June 2020; Accepted: 14 July 2020; Published: 23 July 2020

\begin{abstract}
Emotions are embedded in the everyday life of every individual. In the same way their emotions are immersed in their cultural legacy, they are conditioned by behaviors that cannot be separated from an educational context. In this sense, physical education (PE) has been reported as a school subject that facilitates the emotional expression of primary and secondary school students. Thus, it seems to be important to understand how applied methodologies that enhance emotional education in this context help to develop students' skills regarding emotional management. In this context, 18 articles were selected from the Web of Science (WoS) under robust inclusion and exclusion criteria, which posteriorly were categorized and deeply analyzed. Results show that PE creates a favorable scenario for the expression of emotions. However, there is not sufficient evidence regarding emotional education methodologies that can be applied by PE teachers in their classes to improve primary and secondary students' management of emotions. It has been concluded that more proposals based on scientific evidence in this field are required.
\end{abstract}

Keywords: emotions; motor games; active motor activities; feelings; self-esteem

\section{Introduction}

The emotions of human beings are activated in the brain in response to different stimuli that can be generated internally as well as externally, forging a complex state of the organism which is characterized by the perturbation or the excitement that anticipates an organized answer [1].

Several authors describe emotions as mental responses of an individual, which prepare the body to face the different situations of daily life in the best was as possible [2-5].

In the same way, emotions are strongly connected to an individual's cultural legacy in regard to behaviors that cannot be separated from an educational context [6-9]. Thus, the logic of attaching educational processes to emotional development seems to be fundamental when a teaching-learning method is set in a particular curriculum and, thus, emotional education (EE) has been developed.

EE is defined as a perpetual educative process, which has the intention to strengthen emotional development as an indispensable element that complements cognitive growth, as both elements are essential for an integral personality. EE seeks to improve the management of emotions to enable people to learn how to confront everyday life challenges positively [1], contributing to wellness and to the capacity for self-regulation as well to manage negative states of mood [10]. 
A sensitive stage for children and adolescents' emotional development is during school life, a phase in which they begin to display, with a special strength, the capacity to believe in themselves as well as to improve their confidence and self-image [11-13]. EE seems to be a very important discipline to be practiced in this context. Many methodologies in education have responded historically to the paradigm of lineal pedagogy, as a part of the traditional model of classic constructivism [14], which focused on human construction from cognitive aspects and did not involve the dynamic composition of individuals [15]. However, modern proposals such as the integrate model understand human beings as a biological living system, thus, with a self-organizing and self-regulated nature, they are composed of several dimensions that are connected dynamically, the emotions being a fundamental part of these [16-19]. This model offers a new perspective on how the development of emotions should be supported in all educational processes. Propositions from this approach of non-linear pedagogy establish mechanisms that guide the teaching-learning process through the comprehension of the relationship between the different human dimensions and the ability to learn [20]. This is how EE has achieved a greater importance and reached a higher role in pedagogical practice in school education.

A discipline that has been distinguished in the history of pedagogy, even though it has been linked strongly to the traditional paradigm of classic constructivism, is physical education (PE), which from the early ages has helped to develop integrally a series of dimensions, especially emotions, contributing in a positive manner to multiple variables such as memory, physical self-concept, interpersonal relationships and social behavior [21]. In the same way, this pedagogical area naturally promotes team work, resilience, conviction and discipline, among others, thanks to the diverse methodologies that constitute it such as motor expression, games, individual sports, team sports, outdoors activities, etc. [22].

Physical education has been a fundamental part of the school curriculum, giving students an important amount of time of practice during the whole stay in school education, although decreasing from primary to secondary school [23]. In this way, PE has evolved from being principally focused on sports context to nowadays being centered on the education of healthy behavior conducts related to physical condition and physical activity [24], with the aim to contribute to decreasing and preventing metabolic disorders in adulthood associated with inactivity states, sedentarism and bad nutrition [25]. It is due to these motives that the need to search, to find and to analyze the current state of the published literature arises, with the aim of understanding how EE is associated methodologically with physical education in the school context today.

\section{Materials and Methods}

\section{Procedures}

A bibliographic review of primary sources has been conducted with the objective of synthetizing and posteriorly analyzing the obtained results through the search and selection of published articles regarding EE in the context of scholar education across the practices of physical education. The presented strategy for these effects was to perform the search through the Web of Knowledge (www.webofknowledge.com) database, which nowadays utilizes the name Web of Science (WoS). This platform has a multidisciplinary character, with an interface that allows a deep scientometric and bibliometric management, granting access to an important amount of electronic publications attached to Thomson Reuters records [26].

For the collection process, the following key words were used: emotional education, primary school, secondary school, scholar, children, physical education, sports, physical activity, emotions, and self-concept. For all those concepts composed of more than one word, quotation marks were used. ("an example"). The searching process started by using a multiple combination of key words with the aim to be able to amplify the possibilities to find as many documents as possible (Table 1). These combinations were configured by the classification of title and/or theme, specifying the field 
search of each word through the Boolean operator "AND". The filter of "year of publication" was not used, with the idea of being able to access a higher amount of published work. Filters of "type of document" as well as language preference (English and Spanish) were used, limiting the search to only original articles, reviews, and books, excluding all other kind of documents that could be indexed in the WoS database.

Table 1. Combination of keywords for search process.

\begin{tabular}{cccc}
\hline Title & Theme 1 & Theme 2 & Studies Found \\
\hline "Emotional Education" & - & - & 183 \\
"Emotional Education" & "Primary school" & - & 12 \\
"Emotional Education" & "Secondary School" & - & 4 \\
"Emotional Education" & Children & - & 47 \\
"Emotional Education" & "Physical education" & - & 3 \\
"Emotional Education" & Sports & - & 1 \\
"Emotional Education" & "Physical activity" & - & 0 \\
"Emotional Education" & "Primary school" & "Physical education" & 0 \\
"Emotional Education" & Children & "Physical education" & 0 \\
"Physical education" & "Emotional Education" & - & 9 \\
"Physical education" & emotions & "Primary school" & 6 \\
"Physical education" & emotions & "Secondary School" & 0 \\
"Physical education" & "Self-concept" & "Primary school" & 4 \\
"Physical education" & "Self-concept" & "Secondary School" & 0 \\
"Physical education" & "Self-concept" & Scholar & 2 \\
"Physical education" & Emotions & Scholar & 6 \\
"Physical education" & "Emotional Education" & Scholar & 0 \\
Emotions & "Physical education" & - & 31 \\
Emotions & Scholar & - & 118 \\
Emotions & "Physical education" & "Primary school" & 3 \\
Emotions & "Physical education" & "Secondary School" & 0 \\
\hline
\end{tabular}

At the time that results were obtained for each combination (8 June 2020), the second stage of procedures were started. This was comprised by the registration of titles, authors, year of publication, and abstracts in an Microsoft Excel ${ }^{\circledR} 2019$ spreadsheet, corroborating during and at the end of this process, that all those documents that were found in more than one combination used to perform the searching in WoS were not registered more than one time. In this way, 80 documents were obtained under the frame of the searching categories previously mentioned.

As a third stage, the selected documents were checked by the imposition of a title filter, classifying all articles in the following categories: "documents that possess key words in the title regarding EE and $\mathrm{PE}^{\prime}$ and "documents that do not possess key words in the title regarding EE and PE". In this manner all documents that belonged to the second category were filtered again under the following exclusion criteria: the "Physical Education", "sports", "physical activity" or similar variables are not used to see the effect or their relationship with the variables of "Emotional Education", "emotions", "self-esteem" and/or "self-concept" in the contexts of "scholars" and/or "schools". Once the filter was applied, the same procedure was used for all remaining documents although with the next exclusion criteria: the document presents a context different than "school", "scholars", "Primary school" or "Secondary school". At the end of this stage, the definitive documents were selected with the aim of performing the bibliographic review to respond to the question that motivates the present study (Figure 1). 


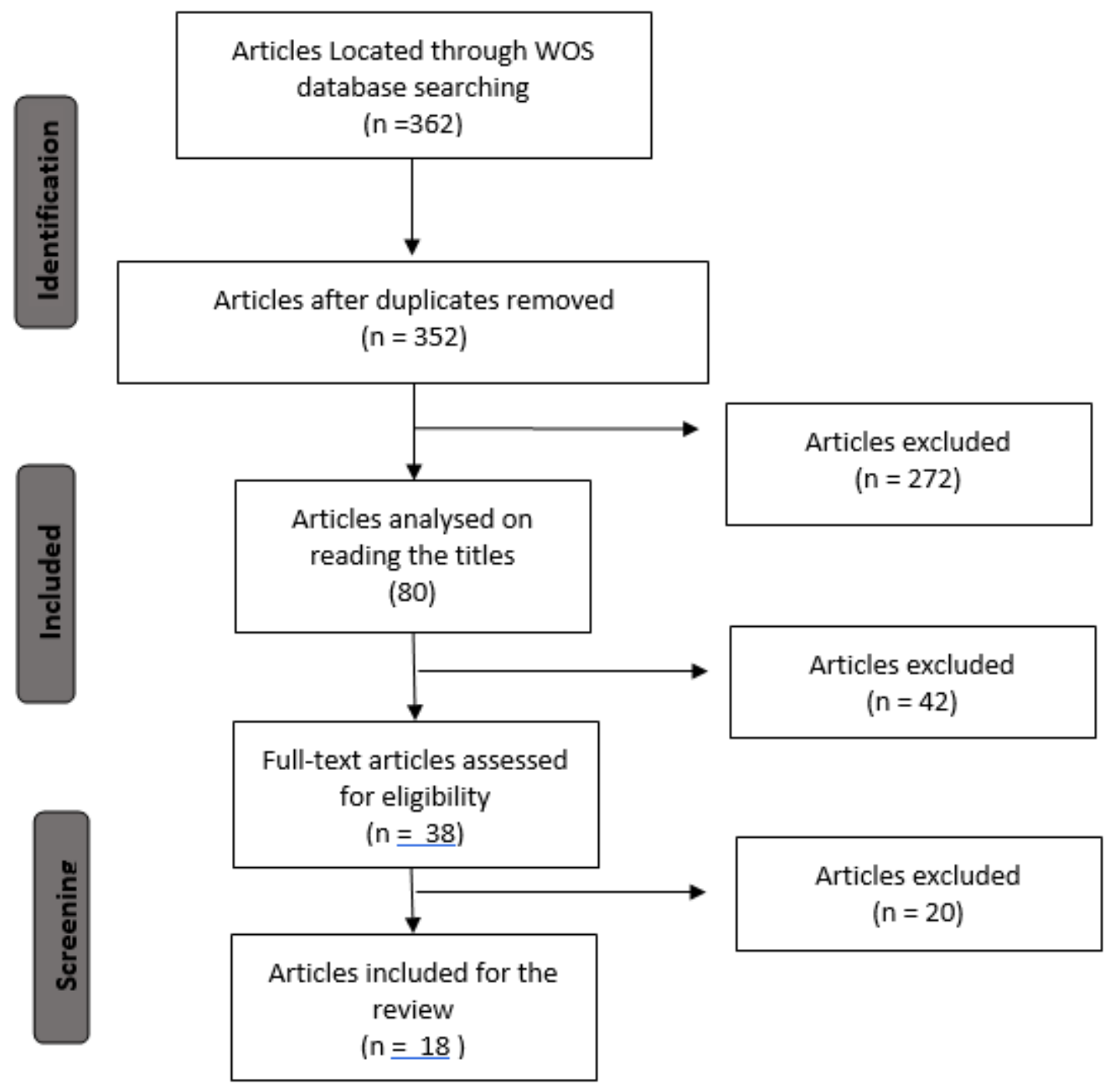

Figure 1. Flowchart of stages adopted in the selection of the articles.

\section{Results}

For the present study, 18 documents were selected. All of these were classified according to their content, date of publication, orientation, contributions, study design, and country sample. As part of the initial analysis, it was identified that $16 \%$ of the reviewed documents were focused on the role and responsibility of the physical education teacher in the context of school education. An amount of $11 \%$ were focused on the development or expression of emotions in secondary school students, while $44 \%$ were centered on the development or the expression of emotions in primary school students. An amount of $22 \%$ were bibliographic reviews, and $5.5 \%$ belonged to critical analysis of theory applied to emotions in the context of physical education in the school. Table 2 shows the classification as previously mentioned. 
Table 2. Descriptive summary of analyzed articles.

\begin{tabular}{|c|c|c|c|c|c|c|}
\hline Title & $\begin{array}{c}\text { Year of } \\
\text { Publication }\end{array}$ & Authors & Contributions & $\begin{array}{c}\text { Study } \\
\text { Design }\end{array}$ & $\begin{array}{l}\text { Sample } \\
\text { Country }\end{array}$ & Orientation \\
\hline $\begin{array}{l}\text { Teaching in Physical Education: } \\
\text { Socialisation, Play and Emotions }\end{array}$ & 2012 & Molina, Fidel & $\begin{array}{l}\text { Demonstrates that PE classes are facilitator } \\
\text { environments for emotional expression. } \\
\text { Teachers have the responsibility to facilitate } \\
\text { the emotional expression of their students. }\end{array}$ & $\begin{array}{l}\text { Descriptive and } \\
\text { interpretative case } \\
\text { of study }\end{array}$ & Spain & $\begin{array}{l}\text { Role and responsibilities of } \\
\text { physical education } \\
\text { (PE) teacher }\end{array}$ \\
\hline $\begin{array}{c}\text { Gender and academic level } \\
\text { differences on scholar physical } \\
\text { education's perceived usefulness at } \\
\text { secondary compulsory education }\end{array}$ & 2013 & $\begin{array}{l}\text { Gomez-Marmol, A.; } \\
\text { De la Cruz-Sanchez, E. }\end{array}$ & $\begin{array}{l}\text { Both genders focus their preoccupations on } \\
\text { health traduced by the hedonist view of body } \\
\text { fitness. "Adolescents" emotions are related to } \\
\text { the worry of having a "non-acceptable body". } \\
\text { Teachers highlight the lack of emotional } \\
\text { education (EE) in their university training to } \\
\text { confront this issue. }\end{array}$ & $\begin{array}{c}\text { Correlational } \\
\text { experimental study }\end{array}$ & Spain & $\begin{array}{l}\text { Role and responsibilities of } \\
\text { PE teacher }\end{array}$ \\
\hline $\begin{array}{l}\text { Physical educationstudent teachers' } \\
\text { perceptions of applying knowledge } \\
\text { and skills about emotional } \\
\text { understanding studied in PETE in a } \\
\text { one-year teaching practicum }\end{array}$ & 2013 & $\begin{array}{c}\text { Klemola, Ulla; } \\
\text { Heikinaro-Johansson, } \\
\text { Pilvikki; } \\
\text { O'Sullivan, Mary }\end{array}$ & $\begin{array}{l}\text { This document reported on the perceptions of } \\
\text { student teachers during their practice in the } \\
\text { school context. They tried to implement } \\
\text { emotional understanding strategies during } \\
\text { this experience. However, they reported } \\
\text { difficulties in performing this well. } \\
\text { More studies and training must be given } \\
\text { in universities. }\end{array}$ & $\begin{array}{l}\text { Descriptive and } \\
\text { interpretative case } \\
\text { of study }\end{array}$ & Finland & $\begin{array}{c}\text { Role and Responsibilities o } \\
\text { PE teacher }\end{array}$ \\
\hline $\begin{array}{l}\text { Relationship between body image, } \\
\text { self-concept and } \\
\text { Physical Education lessons according } \\
\text { to their intensity and enjoyment in } \\
\text { Secondary Education scholars }\end{array}$ & 2013 & Gomez-Marmol, A. & $\begin{array}{l}\text { Explains the perception of self-image and how } \\
\text { this improves during the secondary school } \\
\text { cycle due to the physical work. }\end{array}$ & $\begin{array}{l}\text { Descriptive and } \\
\text { interpretative case } \\
\text { of study }\end{array}$ & Spain & Secondary students \\
\hline $\begin{array}{l}\text { Why are you fighting? Motor } \\
\quad \text { conflicts and negative } \\
\text { Emotions in the physical education } \\
\text { class: The case of opposition games }\end{array}$ & 2014 & $\begin{array}{l}\text { de Ocariz Granja, Unai Saez; } \\
\text { Lavega Burgues, Pere; } \\
\text { Lagardera Otero, } \\
\text { Francisco et al. }\end{array}$ & $\begin{array}{l}\text { Team motor games provide an environment } \\
\text { that can trigger negative emotions if teachers } \\
\text { do not drive the activity correctly. } \\
\text { Demonstrates the importance of } \\
\text { emotional education. }\end{array}$ & $\begin{array}{l}\text { Observational } \\
\text { phenomenological }\end{array}$ & Spain & Secondary school students \\
\hline $\begin{array}{l}\text { Emotional attribution of 6th grade } \\
\text { students in Physical Education } \\
\text { and Health }\end{array}$ & 2016 & $\begin{array}{l}\text { Mujica Johnson, } \\
\text { Felipe Nicolas; } \\
\text { Orellana Arduiz, } \\
\text { Nelly del Carmen; } \\
\text { Aranguiz Aburto, } \\
\text { Hugo Augusto et al. }\end{array}$ & $\begin{array}{l}\text { Contributes to the comprehension of the } \\
\text { dynamics of emotion in a physical education } \\
\text { class. How causal attribution happens in the } \\
\text { class. The study gives a model of } \\
\text { comprehension of the seven most expressed } \\
\text { positive emotions as well as the three most } \\
\text { expressed negative. }\end{array}$ & $\begin{array}{l}\text { Descriptive study, } \\
\text { research-action } \\
\text { qualitative focus }\end{array}$ & Chile & Primary school students \\
\hline
\end{tabular}


Table 2. Cont.

\begin{tabular}{|c|c|c|c|c|c|c|}
\hline Title & $\begin{array}{c}\text { Year of } \\
\text { Publication }\end{array}$ & Authors & Contributions & $\begin{array}{l}\text { Study } \\
\text { Design }\end{array}$ & $\begin{array}{l}\text { Sample } \\
\text { Country }\end{array}$ & Orientation \\
\hline $\begin{array}{l}\text { Emotional intensity in the class of } \\
\text { Physical Education } \\
\text { depending on the victory: } \\
\text { cooperation-opposition games }\end{array}$ & 2016 & $\begin{array}{l}\text { Caballero Garcia, Maria } \\
\text { Fuensanta; Alcaraz Munoz, } \\
\text { Veronica; Alonso Roque, Jose } \\
\text { Ignacio et al. }\end{array}$ & $\begin{array}{l}\text { This study evidences that team motor games } \\
\text { tend to present more positive emotions that } \\
\text { negative. However, in those activities in } \\
\text { which the focus is to win, more positive } \\
\text { emotions are generated compared with those } \\
\text { team motor games that are focused on not } \\
\text { losing. }\end{array}$ & $\begin{array}{l}\text { Quasi-experimental } \\
\text { descriptive study }\end{array}$ & Spain & Primary school students \\
\hline $\begin{array}{l}\text { Emotional physical education } \\
\text { through games in primary education. } \\
\text { Helping teachers to make decisions }\end{array}$ & 2017 & $\begin{array}{c}\text { Miralles Pascual, Rosa; Filella } \\
\text { Guiu, Gemma; Lavega Burgues, } \\
\text { Pere }\end{array}$ & $\begin{array}{l}\text { Presents how motor games help to contribute } \\
\text { to emotional education, especially within } \\
\text { collaborative games. Explains that motor } \\
\text { activities with no competition result in more } \\
\text { positive emotions compared with those with } \\
\text { competition. The role of the PE teacher is } \\
\text { fundamental to modulate and conduct the } \\
\text { activities. }\end{array}$ & $\begin{array}{l}\text { Quasi experimental } \\
\text { descriptive study with } \\
\text { qualitative analysis }\end{array}$ & Spain & Primary school students \\
\hline $\begin{array}{l}\text { Emotions in the Physical Education } \\
\text { Class: Narrative Review (2010-2016) }\end{array}$ & 2017 & $\begin{array}{l}\text { Mujica-Johnson, Felipe-Nicolas et } \\
\text { al. }\end{array}$ & $\begin{array}{l}\text { Presents how games in PE class help to } \\
\text { contribute to emotional expression. It } \\
\text { recommends relaxation activities such as yoga } \\
\text { or stretching. } \\
\text { Competition seems not to be very positive, } \\
\text { however, it is the activity that activates more } \\
\text { emotions. }\end{array}$ & Bibliographic review & Chile & General review \\
\hline $\begin{array}{l}\text { Play in Positive: Gender and } \\
\text { Emotions in Physical Education }\end{array}$ & 2017 & $\begin{array}{l}\text { Alcaraz-Munoz, Veronica; Alonso } \\
\text { Roque, Jose Ignacio; Yuste Lucas, } \\
\text { Juan Luis }\end{array}$ & $\begin{array}{l}\text { Results in this study show the need to better } \\
\text { understand the relationship between motor } \\
\text { games and emotions experimentation. In the } \\
\text { PE field, the use of motor games allows } \\
\text { students to live an important repertoire of } \\
\text { emotional experiences. }\end{array}$ & $\begin{array}{l}\text { Research-action } \\
\text { descriptive study }\end{array}$ & Spain & Primary school students \\
\hline $\begin{array}{l}\text { Emotional education in the subject of } \\
\text { physical education: critical analysis } \\
\text { of the positive or negative value of } \\
\text { emotions }\end{array}$ & 2018 & $\begin{array}{c}\text { Mujica Johnson, Felipe Nicolas; } \\
\text { Orellana Arduiz, Nelly Del } \\
\text { Carmen; Canepa Castillo, Paolo } \\
\text { Ignacio }\end{array}$ & $\begin{array}{l}\text { The analysis explains the importance of } \\
\text { changing the hedonistic perspective of PE in } \\
\text { terms of health associated with a fit body and } \\
\text { move it towards a more integrated concept. }\end{array}$ & Critical analysis & Chile & General review \\
\hline $\begin{array}{l}\text { Multi-Teaching Styles Approach and } \\
\text { Active Reflection: Effectiveness in } \\
\text { Improving Fitness Level, Motor } \\
\text { Competence, Enjoyment, Amount of } \\
\text { Physical Activity, and Effects on the } \\
\text { Perception of Physical Education } \\
\text { Lessons in Primary School Children }\end{array}$ & 2018 & $\begin{array}{l}\text { Invernizzi, Pietro Luigi; Crotti, } \\
\text { Matteo; Bosio, Andrea et al. }\end{array}$ & $\begin{array}{l}\text { The study shows that children who } \\
\text { experienced classes with a model of } \\
\text { multi-teaching style from their PE teachers } \\
\text { improved their physical fitness and motor } \\
\text { expression and their ability to express } \\
\text { their emotions. }\end{array}$ & Quasi experimental & Italy & Primary school students \\
\hline
\end{tabular}


Table 2. Cont

\begin{tabular}{|c|c|c|c|c|c|c|}
\hline Title & $\begin{array}{c}\text { Year of } \\
\text { Publication }\end{array}$ & Authors & Contributions & $\begin{array}{c}\text { Study } \\
\text { Design }\end{array}$ & $\begin{array}{l}\text { Sample } \\
\text { Country }\end{array}$ & Orientation \\
\hline $\begin{array}{l}\text { Emotional experience of university } \\
\text { students in physical education: } \\
\text { systematic review }\end{array}$ & 2019 & $\begin{array}{c}\text { Daniel Martinez-Martinez, } \\
\text { Francisco; Valero-Valenzuela, } \\
\text { Alfonso }\end{array}$ & $\begin{array}{l}\text { The study demonstrates the importance of PE } \\
\text { classes as a facilitator of emotions due to the } \\
\text { several types of environments that can be } \\
\text { produced: motor games, sports, etc. }\end{array}$ & Literature review & Spain & General review \\
\hline $\begin{array}{l}\text { Emotions in Physical Education. A } \\
\text { bibliographic review (2015-2017) }\end{array}$ & 2019 & $\begin{array}{l}\text { Bermudez Torres, Carlos; } \\
\text { Saenz-Lopez, Pedro }\end{array}$ & $\begin{array}{l}\text { This review shows the increasing interest in } \\
\text { research about EE in the context of physical } \\
\text { education and invites more investigations to } \\
\text { be performed. }\end{array}$ & Systematic review & Spain & General review \\
\hline $\begin{array}{l}\text { Gender stereotypes in physical } \\
\text { education }\end{array}$ & 2019 & Carlos Pastor-Vicedo, Juan et al. & $\begin{array}{l}\text { This study highlights a tendency of teachers } \\
\text { to plan motor activities according to males' } \\
\text { preferences over females' preferences, } \\
\text { generating an environment that reduces the } \\
\text { emotional expression of girls. Thus, it } \\
\text { emphasizes the importance of emotional } \\
\text { education for children and teachers. }\end{array}$ & $\begin{array}{l}\text { Interpretative } \\
\text { descriptive study }\end{array}$ & Spain & Primary school students \\
\hline $\begin{array}{c}\text { Project Wonderwall. Emotions' } \\
\text { identification and management in } \\
\text { Primary Education Physical } \\
\text { Education }\end{array}$ & 2019 & $\begin{array}{l}\text { Fernandez-Garcia, Laura; } \\
\text { Fernandez-Rio, Javier }\end{array}$ & $\begin{array}{l}\text { This project offers a methodology for working } \\
\text { on emotional education through activities that } \\
\text { involve motor tasks. It provides evidence of } \\
\text { how children learn how to manage their } \\
\text { emotions better when these are worked } \\
\text { through motor tasks. }\end{array}$ & Pilot project & Spain & Primary school students \\
\hline $\begin{array}{c}\text { Satisfaction in the Physical } \\
\text { Education classroom and intention } \\
\text { to be physically active in Primary } \\
\text { school children }\end{array}$ & 2020 & $\begin{array}{l}\text { Zueck Enriquez, Maria del } \\
\text { Carmen et al. }\end{array}$ & $\begin{array}{c}\text { This study shows that the predisposition to } \\
\text { generate joyful motor activities facilitates } \\
\text { adherence and pleasure in regard to physical } \\
\text { activities. }\end{array}$ & $\begin{array}{l}\text { Mixed focus, qualitative } \\
\text { and quantitative study }\end{array}$ & Spain & Primary school students \\
\hline
\end{tabular}


In terms of date of publication, five articles were published before 2015. These documents focus mainly on the role of the physical education teacher as facilitator of activities that can promote emotional expression [27-29]. Only two of the mentioned documents presents some evidence on student experiences of emotions in physical education class. However, none of them were related to emotional education specifically, only in how emotions are expressed in different conditions of the PE class [30,31]. None of these five documents were centered on primary school; they only focused on secondary school and PE teacher formation. On the other hand, no documents were found in this field of bibliographic review that were published in the year 2015.

Only two documents from 2016 were included in this review. These were both centered on experiences with primary school students. One of them reveals a list of the most expressed emotions (positives and negatives) in PE classes [32], while the other explains that during team motor games, children tend to present more positive emotions than negative ones [33]. Nevertheless, team motor games focused on winning facilitate more positive emotions compared with those focused on not losing. Similarly, only three studies from 2017 were included in this review. In this case, all articles were based on the same aspects, namely how motor games can be an important trigger for the expression of emotions. Differences between these documents were only the type of motor game (teams, competitive, relaxation and recreation) on which the study was focused [34-36]. Again, as well as the previous studies, these concentrated only on the context of primary school students.

Only two studies from 2018 fulfilled the inclusion criteria. The first research compared the traditional model of teaching style in physical education versus a multi-teaching approach. Data revealed that those children who learn by the multi-teaching style are more likely to improve their physical fitness as well as to easily express their emotions compared with those children who learn by the traditional model [37]. On the other hand, the second study revealed the importance of changing the hedonistic perspective of $\mathrm{PE}$, in terms of health associated with a fit body, and moving it towards a more integrated concept [38].

Going forward with the analysis, four articles were accepted in this review. Two of them were bibliographic reviews, one quasi-experimental research and one pilot project. Both reviews made the same conclusions: physical education facilitates the ability to express emotions, and further studies are needed in this area $[39,40]$. On the other hand, the remaining articles focused on primary school students, showing important evidence about how teachers tend to plan activities that are better received by males than females due to a professional bias about genders and physical activity [41], as well as how teachers can apply a didactic and attractive tool to help children to improve their ability to manage their emotions [42].

Finally, during the year 2020 at the time this research was conducted, only one document that fulfilled the inclusion criteria was published. This research offers strong evidence for how joyful physical activities improve the adherence of children to a systematic and committed practice of these types of activities [43].

An important result worth highlighting relates to the country of origin of the samples and authors. Among the total reviewed articles, 5.5\% were performed in Finland; the same percentage (5.5\%) were conducted in Italy; and a higher amount of studies were completed in Chile. Notably, all of the remaining analyzed articles (72.2\%) were developed in Spain. This last country is the one with the greatest evidence of EE from Physical education in the contexts of both primary and secondary school.

\section{Discussion}

The main objective of the present study was to understand how EE is nowadays associated, in terms of methodology, with physical education in the contexts of primary and secondary school. Before discussing this, it seems important to consider certain limitations of the present review.

Despite the large amount of evidence regarding didactics, methodologies and education strategies related to developing emotions in primary and secondary school students, only 18 studies fulfilled our inclusion criteria, leaving the possibility of having left out some studies that may have been 
relevant for this review's purposes. A second limitation could have been the risk of the authors' biases during the analysis process. However, a strong and structured methodology was performed to reduce this possibility.

After the search, selection and categorization of the carefully chosen documents which were deeply analyzed, it is evidently observable that, even though the study of emotions has been conducted for a long period of time, and the evidence of the importance of developing methodologies relevant to the school context and its impact on the ability of students to manage their emotions is largely available [44-46], there are not sufficient published studies regarding these topics in the context of physical education for primary and secondary school in highly ranked databases. This implies that perhaps such studies are unable to give scientific guarantees. Along the same lines, it is possible to observe that the oldest studies have evidenced the importance of physical education classes only in one context, secondary school, involving mainly the responsibility and the role of the physical education teacher. However, in terms of methodology, these initial documents do not give teachers any tools to develop, through didactic techniques, students' emotional expression. Subsequent studies focus on describing how emotions are expressed now in primary school. Nonetheless, without sufficient evidence, this cannot be representative. Most of the studies, although presenting a considerable number of participants, were performed mainly in Spain, thus, they are not representative of other countries, considering that emotions are highly dependent on the subject's culture and education $[6,7]$. An interesting point on which most of the analyzed documents agreed, was that physical education class is still a particular environment where students can express different emotions due to the multi-faceted methodologies that compose this school subject in which different motor games can be performed [28-32,35-37]. Nevertheless, the role of the physical education teacher, due to the lack of preparation during the university period, tends to impair students' management of their emotions for two main reasons. First, there is a notable bias when classes are planned, where teachers develop mainly activities oriented to male students due to the idea that preferences of females are not as active as those of their male counterparts. Second, even though team motor games have been reported as a notable context in which positive emotions emerge, when these are focused on "not losing" instead of on "winning", highly negative emotions arise. It has been reported that teachers tend to determine the aim of the collective motor games as being "trying to not lose again" when losing for the first time [33]. Consistent with the presented literature, subsequent studies have described similar experiences related to team motor games, agreeing with the idea that these sorts of activities during physical education class are very important triggers of emotions. However, other motor activities such yoga or stretching, where relaxation is implied, also seem to be very positive in facilitating the expression of emotions, whereby team motor games should not be the main activity to use in physical education class. However, what seems to be more important than the type of motor activity is the teaching model that is used in class. The reported evidence points out that teachers who use a multi-teaching style positively impact students' capacity to manage their emotions and their ability to increase physical fitness due to the improvement of their emotions associated with commitment, resilience and self-esteem [37].

With regard to the latest studies, a trend of bibliographical reviews seems to be emerging with the aim to describe the value that physical education contributes to EE nowadays. Ciotto and Gagnon [47] have proposed methodologies to address, through physical education, from the early stages, five fundamental elements: self-management, responsible decision-making, relationship management, social awareness, and self-awareness. Although the information provided by the authors seems to be valuable, sensitive stages are not presented regarding the development of these abilities and their specific methodologies within primary or secondary school. In this sense, no variations have been reported so far, concluding that it seems to be important to develop concrete applied strategies during PE class to improve EE. In these terms, the latest study published in the recent year [43], provides strong evidence explaining how joyful activities improve the adherence of children to physical activities. This last experience can be compared with a similar one published in 2013 [48], where dancing, as a joyful and expressive activity, helped to improve social interaction, positive 
emotion management and greater adherence to the activity. In this sense, Farrington and Shewfelt [49] declare that developing and expressing the arts stimulates the intimate components of human beings, profoundly impacting emotions. This situation seems not to be possible to generate with other fields such as mathematics or science. However, this same effect on emotions could be reached through physical education. Nonetheless, the diversity of stimulus, the movement expressions, and the lack of evident methodologies, responses by gender and condition, etc. are not entirely clear and more lines of research are needed.

From 2012 to date, there have been very few investigations concerning EE in the context of physical education at primary and secondary school in countries other than Spain. During the initial phase of this bibliographic review, only three countries other than Spain presented articles under this review's inclusion criteria. This situation may be attributed to a lack of interest in the physical education field in other countries.

\section{Conclusions}

After analyzing the selected articles, all related to EE development in physical education in the framework of primary and secondary school, it is concluded that, although different didactics and methodological strategies of motor activities applied in physical education classes have a very positive effect on students' ability to express emotions, the ability to manage these emotions is highly dependent on the teacher's aptitudes to teach and promote this skill. In the same way, due to the scarce published evidence regarding strategies that teachers can apply, more studies should be conducted in this field to explore other pedagogical experiences, such art, music, and similar school subjects. At the same time, more methodological proposals, specifically for EE development through physical education classes for primary and secondary school, are necessary.

Author Contributions: S.E.-L., R.R.H., P.V.-M. and P.E.-L. contributed to the conceptualization. S.E.-L, R.R.H. and P.V.-M. designed the methodology. All authors contributed to data interpretation of statistical analysis. P.V.-M., R.R.H and C.F.-V. wrote the paper with significant input from S.E.-L. All authors have read and agreed to the published version of the manuscript.

Funding: This research received no external funding.

Conflicts of Interest: The authors declare no conflict of interest.

\section{References}

1. Bisquerra, R.; Pérez-González, J.C.; García, N.E. Inteligencia Emocional en Educación; Editorial Síntesis: Madrid, Spain, 2015; p. 340.

2. Bisquerra, R.; Punset, E.; Mora, F.; García, E.; López-Cassà, È.; Pérez-González, J.; Lantieri, L.; Nambiar, M.; Madhavi, M.; Aguilera, P. ¿ Cómo Educar las Emociones? La Inteligencia Emocional en la Infancia y la Adolescencia; Editorial ; Hospital Sant Joan de Déu: Barcelona, Spain, 2012; p. 126.

3. Cepeda-Hernández, S.L. El mindfulness disposicional y su relación con el bienestar, la salud emocional y la regulación emocional. Revista Internacional de Psicología 2015, 14, 1-31. [CrossRef]

4. Enríquez Argoti, E.; Martínez Romero, J.A.; Guevara Porras, L.M. Relación de la inteligencia emocional con el desempeño laboral. Revista Cincia Salud 2015, 3, 41-46.

5. Ganga, N.S.; Kutty, V.R.; Thomas, I. Determinants of positive mental health: A path model. Mental Health Rev. J. 2014, 19, 47-60. [CrossRef]

6. Mirabel, A.M.; Lain, d.B.B.; Mendo, L.S.; Iglesias, G.D. Predictive role of emotional intelligence and physical activity on the physical self-concept of schoolchildren. Sport. Sci. Tech. J. Sch. Sport Phys. Educ. Psychomot. 2020, 6, 308-326.

7. Herrea, L.; Al-Lal, M.; Mohamed, L. Academic Achievement, Self-Concept, Personality and Emotional Intelligence in Primary Education. Analysis by Gender and Cultural Group. Front. Psychol. 2020, 10, 3075. [CrossRef] 
8. Acebes-Sanchez, J.; Diez-Vega, I.; Esteban-Gonzalo, S.; Rodriguez-Romo, G. Physical activity and emotional intelligence among undergraduate students: A correlational study. BMC Public Health 2019, 19, 1241. [CrossRef]

9. Luna, P.; Guerrero, J.; Cejudo, J. Improving Adolescents' Subjective Well-being, Trait Emotional Intelligence and Scoail Anxiety through a programme Based on the Sport Education model. Int. J. Environ. Res. Public Health 2019, 16, 1821. [CrossRef]

10. Álvarez, M.; Bisquerra, R.; Fita, E.; Martínez, F.; Pérez, N. Evaluación de programas de educación emocional. Rev. Investig. Educ. 2000, 18, 587-599.

11. Bisquerra, R.; Hernández, S. Psicología positiva, educación emocional y el programa aulas felices. Psychol. Pap. 2017, 38, 58-65.

12. Pérez-Escoda, N.; Filella, G.; Alegre, A.; Bisquerra, R. Desarrollo de la competencia emocional de maestros y alumnos en contextos escolares. Rev. Electron. Investig. Psicoeduc. Psigopedag. 2018, 10, 1183-1208. [CrossRef]

13. Calleja, L.S.; Gómez, G.R.; Jiménez, E.G. Desarrollo de competencias emocionales a través del Programa AEdEm para Educación Secundaria. Rev. Complot. Educ. 2018, 29, 975-994.

14. Alvarado, C. Ambientes de aprendizaje en Física: Evolución hacia ambientes constructivistas. Lat. Am. J. Phys. Educ. 2015, 9, S1202-1-S1202-5.

15. Kalina, C.; Powell, K.C. Cognitive and social constructivism: Developing tools for an effective classroom. Education 2009, 130, 241-250.

16. Chow, J.Y.; Davids, K.; Button, C.; Shuttleworth, R.; Renshaw, I.; Araújo, D. The role of nonlinear pedagogy in physical education. Rev. Educ. Res. 2007, 77, 251-278. [CrossRef]

17. Badjanova, J.; Ilisko, D. Holistic philosophy based teaching approaches in Latvian primary schools: Primary education teachers' view. REEP 2014, 7, 22-28.

18. Chapaev, N.K.; Choshanov, M.A. The Strategy for Creation of the Modern Concept of Integrative-Holistic Education (A Case Study of Mining Schools of the Urals). Obraz. Ina. Educ. Sci. 2017, 19, 51-71.

19. Cavero, M. Inteligencia emocional y rendimiento académico en alumnos de educación secundaria obligatoria. REOP 2019, 30, 75-92. [CrossRef]

20. Chow, J.Y.; Teo-Koh, S.M.; Tan, W.K.; Tan, S.J.; Button, C.M.; Kapur, M.; Choo, Z.Y. Nonlinear Pedagogy and its Relevance for the New PE Curriculum; NIE Research Brief Series No. 19-0122019; National Institute of Education: Singapore, 2019; pp. 1-2.

21. Pastor, V.M.L.; Brunicardi, D.P.; Arribas, J.C.M.; Aguado, R.M. Los retos de la Educación Física en el Siglo XXI. Retos 2016, 29, 182-187.

22. Soto, C.Á.; Vargas, J.J. Cuerpo, corporeidad y educación: Una mirada reflexiva desde la Educación Física. Retos 2019, 35, 413-421.

23. Doña, A.M. La educación física chilena en educación básica: Una caracterización crítica. J. Lat. Am. Socio-Cult. Stud. Sport 2018, 9, 65-78.

24. Baena, A.C. La promoción de la salud en la Educación Física escolar: Situación actual y recomendaciones. EmásF Rev. Digit. Educ. Física 2016, 41, 83-95.

25. Pueyo, Á.P.; Alcalá, D.H.; Calvo, G.G.; Río, J.F. Muévete conmigo, un proyecto de aprendizaje servicio en el contexto de la educación física, la actividad física y el deporte. Publ. Fac. Educ. Humanid. Campus Melilla 2019, 49, 181-196.

26. Rosa-Guillamón, A. Revisión bibliográfica de la relación entre condición física y autoconcepto. J. Sport Health Res. 2019, 11, 117-128.

27. Gómez-Mármol, A.; De la Cruz, E. Gender and academic level differences on Scholar Physical Education's perceived usefulness at Secondary Compulsory Education. J. Sport Health Res. 2013, 5, 193-202.

28. Klemola, U.; Heikinaro-Johansson, P.; O'Sullivan, M. Physical education student teachers' perceptions of applying knowledge and skills about emotional understanding studied in PETE in a one-year teaching practicum. Phys. Educ. Sport Pedagog. 2013, 18, 28-41. [CrossRef]

29. Gómez-Mármol, A. Relationship between body image self-concept and Physical Education lessons according to their intensity and enjoyment in Secondary Education scholars. Eur. J. Hum. Mov. 2013, 31, 99-109.

30. Sáez, U.; Lavega, P.; Lagardera, J.; Costes, A.; Serna, J. ¿Por qué te peleas? Conflictos motores y emociones negativas en la clase de Educación Física: El caso de los juegos de oposición. Education XX1 2014, 32, 71-90.

31. Mujica, J.F.N.; Orellana, A.N.; Aranguiz, A.H.A.; Gonzalez, F.H.I. Emotional attribution of 6th grade students in Physical Education and Health. Educ. Física Cienc. 2016, 18, 1-6. 
32. Caballero, G.M.F.; Alcaraz, M.V.; Alonso, R.J.I.; Yuste, L.J.L. Emotional intensity in the class of Physical Education depending on the victory: Cooperation-opposition games. REIFOP 2016, 19, 123-133.

33. Miralles, P.R.; Filella, G.G.; Lavega, B.P. Emotional physical education through games in primary education. Helping teachers to make decisions. Retos 2017, 31, 88-93.

34. Mujica-Johnson, F.N.; del Carmen, O.-A.N.; Concha-Lopez, R.F. Emotions in the Physical Education Class: Narrative Review (2010-2016). Agora para la Educ. Física y el Deporte 2017, 19, 119-134. [CrossRef]

35. Alcaraz-Muñoz, V.; Roque, J.I.; Lucas, J.L. Play in Positive: Gender and Emotions in Physical Education. Apunt. Educ. Física Esports 2017, 129, 51-63. [CrossRef]

36. Invernizzi, P.L.; Crotti, M.; Bosio, A.; Cavaggioni, L.; Alberti, G.; Scurati, R. Multi-teaching styles approach and active reflection: Effectiveness in improving fitness level, motor competence, enjoyment, amount of physical activity, and effects on the perception of physical education lessons in primary school children. Sustainability 2019, 11, 405. [CrossRef]

37. Johnson, F.N.; Arduiz, N.D.; Castillo, P.I. Emotional education in the subject of physical education: Critical analysis of the positive or negative value of emotions. Dilemas Contemp. Educ. Política Valore 2018, 6, 1-23.

38. Martínez-Martínez, F.; Valero-Valenzuela, A. Vivencia emocional del alumnado universitario en educación física: Revisión sistemática. Revista Iberoamericana de Psicología del Ejercicio y el Deporte 2019, 14, 91-96.

39. Torres, C.B.; Buñuel, P.S. Emociones en Educación Física: Una revisión bibliográfica (2015-2017). Retos Nuevas Tend. Educ. Física Deporte Recreación 2019, 36, 597-603.

40. Pastor-Vicedo, J.C.; Sánchez-Oliva, A.; Sánchez-Blanchart, J.; Martínez-Martínez, J. Estereotipos de género en educación física. SPORT TK-Rev. Euroam. Cienc. Deporte 2019, 20, 23-31. [CrossRef]

41. Fernández, G.L.C.; Fernández, R.F.J. Project Wonderwall. Emotions' identification and management in Primary Education Physical Education. Retos 2019, 35, 381-386.

42. Enríquez, M.D.; García, A.A.; Villalobos, J.M.; Gutiérrez, H.E. Satisfaction in the Physical Education classroom and intention to be physically active in Primary school children. Retos 2020, 37, 33-40.

43. Diekstra, R.F.; Gravesteijn, C. Effectiveness of school-based social and emotional education programmes worldwide. Soc. Emot. Educ. Int. Anal. 2008, 1, 255-312.

44. Ellis, A. Emotional education in the classroom: The living school. J. Clin. Child Adolesc. Psychol. 1972, 1, 19-22. [CrossRef]

45. Humphrey, N.; Curran, A.; Morris, E.; Farrell, P.; Woods, K. Emotional intelligence and education: A critical review. Educ. Psychol. 2007, 27, 235-254. [CrossRef]

46. $\mathrm{Xu}, \mathrm{J}$. Homework emotion management at the secondary school level: Antecedents and homework completion. Teach. Coll. Rec. 2011, 113, 529-560.

47. Ciotto, C.M.; Gagnon, A.G. Promoting social and emotional learning in physical education. Am. J. Health Educ. 2018, 89, 27-33. [CrossRef]

48. Rouhiainen, L.; Hämäläinen, S. Emotions and feelings in a collaborative dance-making process. Int. J. Educ. Arts 2013, 14, 1-11.

49. Farrington, C.; Shewfelt, S. How Arts Education Supports Social-Emotional Development: A Theory of Action. State Educ. Stand. 2020, 20,31-35.

(C) 2020 by the authors. Licensee MDPI, Basel, Switzerland. This article is an open access article distributed under the terms and conditions of the Creative Commons Attribution (CC BY) license (http://creativecommons.org/licenses/by/4.0/). 